\title{
PENGARUH E-LEARNING UNTUK MENINGKATKAN DAYA MATEMATIK MAHASISWA
}

\author{
R. Poppy Yaniawati \\ FKIP Universitas Pasundan (email: opyaniawati@yahoo.com)
}

\begin{abstract}
Abstrak: Pengaruh E-learning untuk Meningkatkan Daya Matematik Abstrak: Pengaruh E-learning untuk Meningkatkan Daya Matematik Mahasiswa. Peran integrasi teknologi pada pembelajaran modern cukup penting guna terjadinya proses percepatan dalam peningkatan daya matematika (mathematical power) secara optimal. Penelitian ini mengungkapkan pengaruh e-learning untuk meningkatkan daya matematika. Subjek penelitian ini adalah mahasiswa semester IV pada dua level LPTK yang berbeda. Teknik pengumpulan data dengan tes dan teknik analisis data dengan statistik anova dua jalur. Berdasarkan hasil analisis data, diperoleh bahwa daya matematika mahasiswa yang pembelajarannya melalui blended learning lebih baik dibandingkan melalui full e-learning dan konvensional. Tetapi, daya matematika mahasiswa yang pembelajarannya melalui full e-learning kurang baik dibandingkan melalui pembelajaran konvensional. Dengan demikian, peran guru dalam pembelajaran matematika tidak dapat tergantikan oleh teknologi informasi. Terdapat korelasi yang signifikan antara daya matematik dengan pengetahuan awal, tetapi tidak terdapat korelasi yang signifikan antara daya matematik dan durasi login.
\end{abstract}

Kata Kunci: e-learning, daya matematik, blended learning

Abstract: Influence of E-learning to Improve Students' Mathematical Power. The role of technology on modern learning is essential to the acceleration process in the improvement of mathematical power. This research describes the influence of elearning to improve mathematical power. The subject is the fourth semester students at two Universities. The results show that students who learned through blended learning method are much better in mathematical power than students who learned through full e-learning or conventional approaches. Furthermore, students who learned through e-learning are worse than students used conventional method. Therefore, this indicates that the role of teachers in the mathematics learning process can not be replaced by information technology. In addition, there is a significant correlation between mathematical power and pre-knowledge, on the other hand there is no a significant correlation between mathematical power and login duration.

Keywords: e-learning, mathematical power, blended learning 


\section{PENDAHULUAN}

Pembelajaran kontemporer menuntut peserta didik lebih berperan aktif dalam menggali dan mengembangkan pengetahuan. Aktivitas peserta didik merupakan inti dari proses pembelajaran di masa depan. Dengan demikian, posisi guru dalam sistem pembelajaran kontemporer lebih banyak sebagai fasilitator daripada sebagai instruktur. Kecenderungan perubahan posisi peserta didik dan peran guru tersebut mengakibatkan adanya suatu perubahan paradigma pembelajaran yang mempersiapkan peserta didik menjadi orang yang dapat belajar secara mandiri (independent leaners).

$\operatorname{NCTM}(2000: 4)$ mengemukakan bahwa peserta didik harus mempelajari matematika dengan pemahaman. Artinya, peserta didik secara aktif membangun pengetahuan baru dari pengalaman dan pengetahuan yang dimiliki sebelumnya. Untuk mewujudkan hal itu, dirumuskan empat tujuan umum pembelajaran matematika, yaitu (1) belajar untuk berkomunikasi (mathematical communication); (2) belajar untuk bernalar (mathematical reasoning); (3) belajar untuk memecahkan masalah (mathematical problem solving); (4), belajar untuk mengkaitkan ide (mathematical connections). Kemampuan tersebut biasa disebut dengan istilah daya matematik (mathematical power).

Pada masa globalisasi ini, untuk mengembangkan kemampuan tersebut diperlukan suatu percepatan (acceleration) dalam proses pembelajaran matematika, karena pembaharuan informasi seringkali terjadi begitu cepat. Dengan adanya suatu percepatan, peserta didik dapat mempunyai wawasan ke arah masa depan yang lebih luas. Dalam konteks percepatan, peran teknologi sangatdiperlukan. UNESCO (Chaeruman, 2004:5) menyatakan bahwa pengintegrasian teknologi telekomunikasi dan informasi ke dalam pembelajaran memiliki tiga tujuan untuk: (1) membangun "knowledge-based siciaty habits"; (2) mengembangkan keterampilan menggunakan teknologi (ICT literacy); dan (3) meningkatkan efektifitas dan efisiensi proses pembelajaran.

Sistem e-learning merupakan bentuk implementasi pembelajaran yang memanfaatkan teknologi yang berbasis web. Banyak pakar pendidikan memberikan definisi mengenai e-learning, seperti yang dipaparkan oleh Cute, dkk (1999), "E-learning is instructional content or learning experiences delivered or enabled by electronic technology". Thompson, dkk (2000:8) menyebutkan kelebihan e-learning yang dapat memberikan fleksibilitas, interaktifitas, kecepatan, visualisasi melalui berbagai kelebihan dari masing-masing teknologi. Menurut Linde (2004:2) e-learning adalah pembelajaran baik secara formal maupun informal yang dilakukan melalui media elektronik, seperti internet, intranet, CDROM, videotape, DVD, TV, handphone, PDA, dan lain-lain.

UNESCO (Chaeruman, 2004:7) menglasifikasikan tahap penggunaan teknologi telekomunikasi informasi dalam pembelajaran ke dalam empat tahap. Pertama, emerging, baru menyadari akan pentingnya teknologi informasi untuk pembelajaran dan belum berupaya untuk menerepkannya. Kedua, applying, satu langkah lebih maju di 
mana teknologi informasi telah dijadikan sebagai objek untuk dipelajari (mata pelajaran). Ketiga, integrating, teknologi informasi telah diintegrasikan ke dalam kurikulum (pembelajaran). Keempat, transforming, tahap yang paling ideal, yaitu teknologi informasi telah menjadi katalis bagi perubahan/evolusi pendidikan.

Di negara berkembang seperti Indonesia, teknologi informasi dalam praktik pembelajaran masih dijadikan objek atau mata pelajaran. Penggunaan teknologi informasi masih dalam tahap emerging dan applying, akan menuju pada tahap integrating. Akan tetapi, beberapa negara sudah mulai memanfaatkan teknologi informasi dalam proses pembelajaran, yaitu melalui e-learning. Pemanfaatan teknologi tersebut, selain sebagai upaya mengatasi permasalahan teknis pembelajaran, juga sebagai upaya untuk menjawab masalah substansial pembelajaran.

E-learning dapat juga digunakan untuk mengatasi kekurangan suatu sistem pembelajaran, misalnya pada sistem pembelajaran jarak jauh (distance learning). Dalam penelitian ini, peneliti terdorong untuk melakukan kajian terhadap implementasi e-learning dalam meningkatkan salah satu kemampuan yang harus dikuasai oleh mahasiswa program pendidikan matematika, yakni daya matematik. Tujuan kajian ini adalah (1) menelaah perbedaan daya matematik mahasiswa keguruan yang belajarnya melalui full e-learning, blended learning, dan pembelajaran konvensional; (2) menelaah keterkaitan di antara pengetahuan awal, durasi login, dan daya matematik.

\section{METODE}

Penelitian ini dilaksanakan dengan pendekatan eksperimental (pretest-posttest control group design) dengan dua perlakuan pada kelompok yang berbeda dan kelompok kontrol. Kelompok pertama disebut kelompok eksperimen1, yaitu diberi perlakuan full e-learning $\left(X_{1}\right)$, kelompok kedua disebut kelompok eksperimen-2, yaitu diberi perlakuan blended learning $\left(\mathrm{X}_{2}\right)$, dan kelompok ketiga tanpa memperoleh perlakuan khusus, yaitu pembelajaran berjalan sebagaimana biasa (konvensional) disebut kelompok kontrol $\left(\mathrm{X}_{0}\right)$, yang disajikan dengan desain sebagai berikut.

$\begin{array}{llll}\text { A : } & \mathrm{O}_{1} & \mathrm{X}_{0} & \mathrm{O}_{2} \\ \mathrm{~A}: & \mathrm{O}_{1} & \mathrm{X}_{1} & \mathrm{O}_{2} \\ \mathrm{~A}: & \mathrm{O}_{1} & \mathrm{X}_{2} & \mathrm{O}_{2}\end{array}$

Keterangan:

A : Pemilihan secara acak

$\mathrm{O}_{1}$ : Tes pengetahuan awal

$\mathrm{O}_{2}$ : Tes daya matematik

$\mathrm{X}_{0}$ : Pembelajaran konvensional

$X_{1}$ : Perlakuan dengan full e-learning

$\mathrm{X}_{2}$ : Perlakuan dengan blended learning

Desain eksperimen yang lebih spesifik digunakan untuk mengukur HOTS adalah dua jalur $2 \times 2 \times 3$ model factorial, masing-masing adalah 2 level perguruan tinggi, 2 level pengetahuan awal mahasiswa (unggul dan asor), dan 3 model pembelajaran (full e-learning, blended learning, dan konvensional). Level perguruan tinggi dilihat dari perolehan nilairata-rata Ujian Akhir Nasional(UAN) Sekolah Menengah Umum (SMU), yaitu perguruan tinggi level A dengan ratarata nilai UAN SMU sebesar 8,42 lebih baik dibandingkan dengan perguruan tinggilevelBdengan rata-rata nilai UAN SMU sebesar 7,15. Secara skematik 
desain penelitian ini disajikan pada Tabel 1.

Uji hipotesis yang digunakan dalam penelitian ini adalah uji Anova dua jalur. Uji ini digunakan untuk mengetahui ada atau tidaknya perbedaan daya matematik mahasiswa berdasarkan model pembelajaran (full e-learning, blended learning, dan konvensional), pengetahuan awal mahasiswa (unggul dan asor), dan level perguruan tinggi. Untuk melihat kelompok mana yang lebih baik dibanding yang lain, maka dilanjutkan dengan uji Scheffe. Selain itu, uji ini juga digunakan untuk melihat interaksi dari ketiga faktor tersebut.
Teknik pengambilan sampel yang digunakan adalah purposive sampling untuk yang mewakili level perguruan tinggi dan tahun ajaran akademik mahasiswa. Selanjutnya, untuk penentuan kelompok eksperimen-1, eksperimen-2, dan kontrol dilakukan cara random sampling. Banyaknya mahasiswa yang menjadi sampel adalah 162 orang, yang terdiri dari 90 orang dari perguruan tinggi level A dan 72 orang dari perguruan tinggi level B. Pengetahuan awal dalam penelitian ini merupakan kemampuan prasyarat mahasiswa pada mata kuliah aljabar linear.

\section{Tabel 1. Desain Penelitian}

\begin{tabular}{|c|c|c|c|c|}
\hline \multirow{2}{*}{$\begin{array}{l}\text { Level } \\
\text { Perguruan } \\
\text { Tinggi }\end{array}$} & \multirow[t]{2}{*}{ Pengetahuan Awal } & \multicolumn{3}{|c|}{ Daya Matematik } \\
\hline & & $\begin{array}{l}\text { Kontrol } \\
\left(X_{0}\right)\end{array}$ & $\begin{array}{l}\text { Eksp-1 } \\
\left(X_{1}\right)\end{array}$ & $\begin{array}{l}\text { Eksp-2 } \\
\left(X_{2}\right)\end{array}$ \\
\hline & Unggul & DMUA-K & DMUA-1 & DMUA-2 \\
\hline \multirow[t]{3}{*}{ A } & Asor & DMAsA-K & DMAsA-1 & DMAsA-2 \\
\hline & Total & DMA-K & DMA-1 & DMA-2 \\
\hline & Unggul & DMUB-K & DMUB-1 & DMUB-2 \\
\hline \multirow[t]{2}{*}{ B } & Asor & DMAsB-K & DMAsB-1 & DMAsB-2 \\
\hline & Total & DMB-K & DMB-1 & DMB-2 \\
\hline $\begin{array}{l}\text { Gabungan } \\
\text { Kelompok } \\
\text { A dan B }\end{array}$ & Total & DM-K & DM-1 & DM-2 \\
\hline
\end{tabular}

\section{Keterangan :}

-1 : kelompok eksperimen -1

-2 : kelompok eksperimen-2

-K : kelompok kontrol

A : Perguruan Tinggi level A

B : Perguruan Tinggi level B

$\mathrm{U}$ : mahasiswa unggul

As : mahasiswa asor

DM: daya matematik mahasiswa

\section{HASIL}

Hasil perhitungan statistik deskriptif data pada kedua level perguruan tinggi, yaitu perguruan tinggi level A dan perguruan tinggi level $\mathrm{B}$ terlihat pada Tabel 2.

Tabel 2 memperlihatkan bahwa rerata nilai pengetahuan awal mahasiswa sebelum perlakuan e-learning dari ke- 
tiga kelompok (full e-learning, blended learning, dan konvensional) pada kedua level perguruan tinggi tersebut adalah relatif sama dengan standar deviasi yang relatif sama juga. Namun setelah kedua kelompok mendapatkan e-learning (full e-learning dan blended learning), daya matematik ketiga kelompok pada kedua level perguruan tinggi tersebut adalah relatif berbeda, blended learning lebih baik daripada kelompok lainnya (full e-learning dan konvensional).

Data rerata skor daya matematik mahasiswa dikelompokkan berdasarkan level kemampuan awalnya, dapat dilihat pada Tabel 3.
Tabel 3 memperlihatkan bahwa rerata skor daya matematik kelompok unggul pada kedua level perguruan tinggi dan kelompok asor pada level A yang pembelajarannya dengan blended learning lebih baik daripada yang lain (full e-learning dan konvensional), tapi daya matematik kelompok konvensional lebih baik dari full e-learning. Rerata skor daya matematik kelompok asor pada perguruan tinggi level Byang pembelajarannya full e-learning lebih baik daripada konvensional, walaupun daya matematik yang pembelajarannya dengan blended learning lebih baik dibanding yang lain (full e-learning dan konvensional).

\section{Tabel 2. Statistik Deskripsi Daya Matematik Berdasarkan Pengetahuan Awal dan Level Perguruan Tinggi}

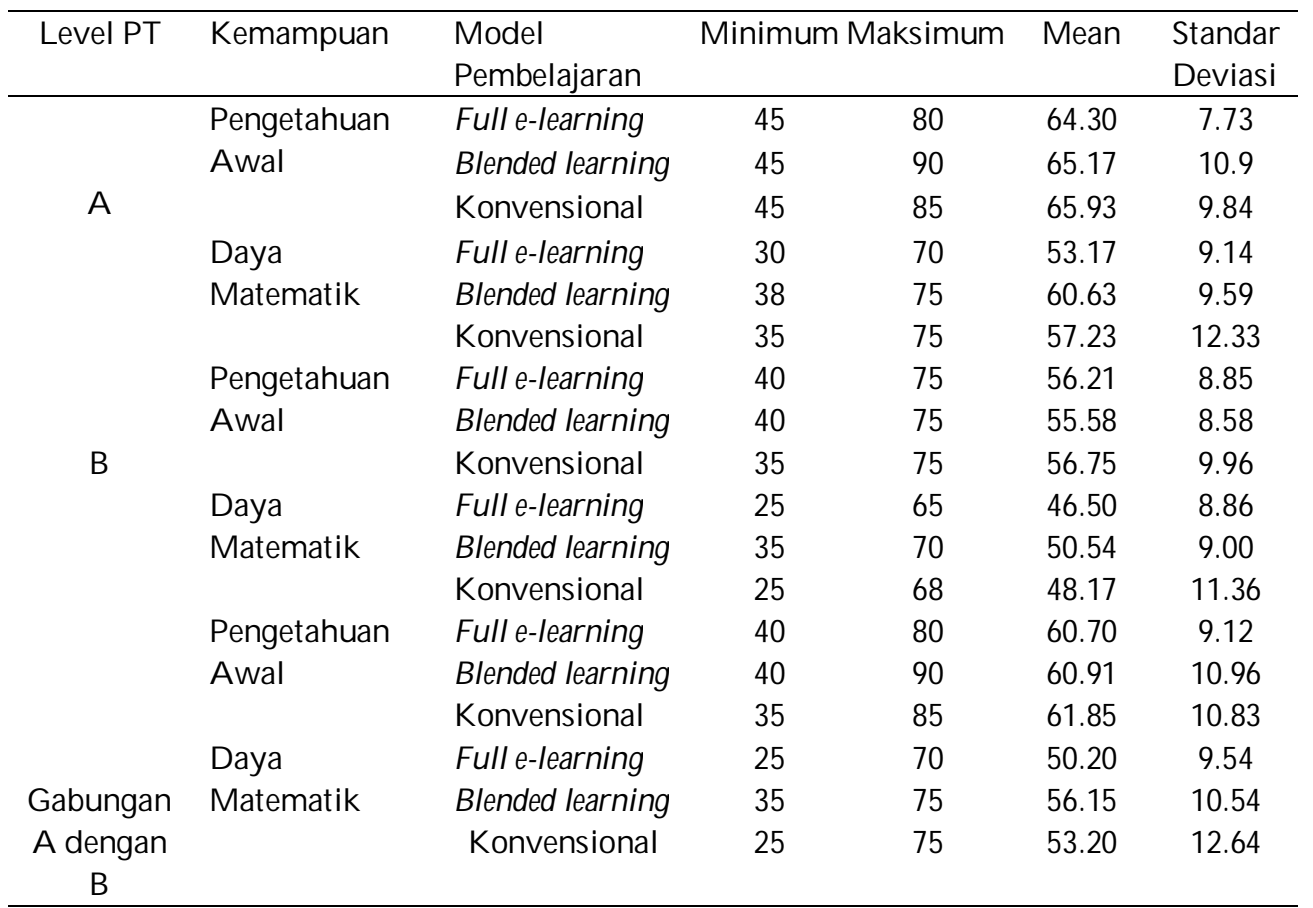

Catatan: nilai ideal adalah 100 
Table 3. Data Skor Rerata Daya Matematik Mahasiswa

\begin{tabular}{clllll}
\hline \multirow{2}{*}{ Level PT } & $\begin{array}{l}\text { Pengetahuan } \\
\text { Awal }\end{array}$ & $\begin{array}{c}\text { Full e-learning } \\
\left(\mathrm{X}_{1}\right)\end{array}$ & $\begin{array}{c}\text { Blended learning } \\
\left(\mathrm{X}_{2}\right)\end{array}$ & $\begin{array}{c}\text { Konventional } \\
\left(\mathrm{X}_{3}\right)\end{array}$ & \multirow{2}{*}{ Mean } \\
\cline { 3 - 5 } & & Mean $(\mathrm{SD})$ & Mean $(\mathrm{SD})$ & Mean $(\mathrm{SD})$ & \\
\hline \multirow{2}{*}{ A } & Unggul & $59,00(5,57)$ & $68,13(4,96)$ & $65,00(8,02)$ & 64,04 \\
& Asor & $46,50(7,80)$ & $53,13(6,73)$ & $47,08(9,20)$ & 48,90 \\
& Total & $53,17(9,14)$ & $60,63(9,59)$ & $57,23(12,33)$ & 57,01 \\
& Unggul & $52,80(7,12)$ & $59,30(5,31)$ & $56,73(6,51)$ & 56,28 \\
B & Asor & $42,00(7,17)$ & $44,29(4,75)$ & $40,92(9,38)$ & 42,40 \\
& Total & $46,50(8,86)$ & $50,54(8,99)$ & $48,17(11,35)$ & 48,40 \\
& Unggul & $56,62(6,81)$ & $64,60(6,67)$ & $61,75(8,41)$ & 60,99 \\
Gabungan & Asor & $44,25(7,70)$ & $48,86(7,30)$ & $44,00(9,63)$ & 45,70 \\
A and B & Total & $50,20(9,54)$ & $56,15(10,54)$ & $53,20(12,65)$ & 53,18 \\
\hline
\end{tabular}

Note: nilai ideal adalah 100

Kita juga dapat melihat korespon- model pembelajaran yang disajikan densi antara pengetahuan awal dan pada Grafik 1.

\section{Estimated Marginal Means of DM}

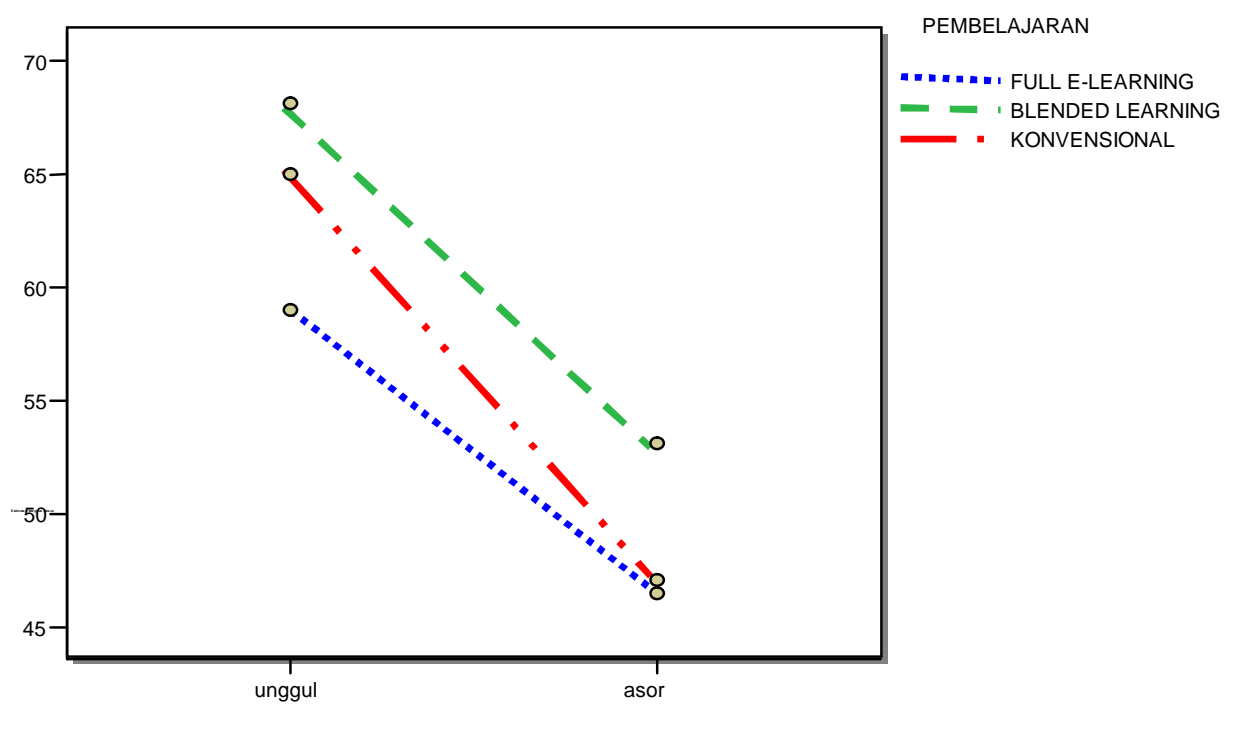

PENGETAHUAN AWAL

Grafik 1. Korespondensi Pengetahuan awal dan Model Pembelajaran pada Perguruan Tinggi Level A 
Tabel 4. Distribusi Banyaknya Mahasiswa dalam Daya Matematik Berdasarkan Pengetahuan Awal

\begin{tabular}{|c|c|c|c|c|c|c|c|c|c|}
\hline & \multicolumn{3}{|c|}{ Full E-Learning } & \multicolumn{3}{|c|}{ Blended Learning } & \multicolumn{3}{|c|}{ Konvensional } \\
\hline $\mathrm{PA}$ & Unggul & Asor & Total & Unggul & Asor & Total & Unggul & Asor & Total \\
\hline Tinggi & 7 & 6 & 13 & 14 & 5 & 19 & 12 & 4 & 16 \\
\hline Rendah & 19 & 22 & 41 & 12 & 23 & 35 & 14 & 24 & 38 \\
\hline Total & 26 & 28 & 54 & 26 & 28 & 54 & 26 & 28 & 54 \\
\hline
\end{tabular}

Grafik 1 memperlihatkan bahwa tidak terdapat interaksi antara pengetahuan awal dan model pembelajaran. Dengan kata lain, tidak terdapat pengaruh pengetahuan awal terhadap ketiga model pembelajaran tersebut. Untuk mengetahui distribusi banyaknya mahasiswa dalam daya matematik berdasarkan pengetahuan awalnya pada full e-learning, blended learning, dan konvensional dapat dilihat pada Tabel 4.

Tabel 4 menggambarkan sebagian besar mahasiswa asor mempunyai daya matematik rendah. Mahasiswa unggul pada kelompok full e-learning hanya beberapa yang mempunyai daya matematik yang tinggi, bahkan lebih banyak yang rendah, tetapi pada kelompok blended learning dan kelompok konvensional mahasiswa unggul dalam keadaan moderat. Hal ini mengindikasikan bahwa pengetahuan awal cukup mempengaruhi daya matematik mahasiswa.

\section{PEMBAHASAN}

Berdasarkan hasil yang diperoleh dari ketiga kelompokpembelajaran pada semua level perguruan tinggi, daya matematik mahasiswa masih termasuk kedalam kategori belum baik. Artinya, belum mencapai kriteria yang diharapkan, yaitu tercapainya efektivitas bela- jar baik secara individu maupun kelompok. Sebagian besar mahasiswa pada kedua perguruan tinggi masih merasa kesulitan dalam menyelesaikan soalsoal yang memuat semua aspek daya matematik (pemecahan masalah, penalaran, komunikasi matematik, dan koneksi matematik), terutama pada soalsoal yang memerlukan suatu penjelasan atas jawaban dari soal-soal tersebut. Daya matematik yang sudah lebih baik adalah kemampuan koneksi matematika, sedangkan yang masih kurang adalah kemampuan penalaran (deduksi) dalam membuktikan suatu pernyataan atau teorema.

Kemampuan koneksimatematik, pemecahan masalah, dan komunikasi matematik kelompokmahasiswa unggul secara parsial lebih baik dibandingkan dengan kemampuan penalaran (deduksi). Sehubungan dengan fakta tersebut, kemampuan berpikir abstrak dan pengembangan kreativitas individual pada seluruh kelompok belajar, perlu menjadi perhatian. Hal itu didukung pula oleh fakta terdapat sedikit perbedaan cara mahasiswa menuangkan gagasannya dari masing-masing kelompok (full e-learning, blended learning, dan konvensional). Jawaban yang benar atas soalsoal daya matematik, mayoritas dari 
kelompok blended learning. Walaupun masih terdapat jawaban yang salah, tetapi mereka sudah berusaha menjawabnya. Berbeda halnya pada kelompok lain (full e-learning dan konvensional), mayoritas mahasiswa tidak menjawab sama sekali (mengosongkan) jawaban soal-soal tipe analisis ini. Berdasarkan fakta tersebut, dapat terlihat bahwa blended learning dapat memperluas wawasan mahasiswa dan menumbuhkan cara berpikir kreatif. Sejalan dengan pendapat Soekartawi (2003:10) bahwa belajar melalui internet dapat menambah ilmu pengetahuan dan wawasan yang lebih luas.

Pada perguruan tinggi level A dan gabungan kedua perguruan tinggi, hasil uji daya matematik mahasiswa pada model blended learning lebih baik dari model yang lainnya. Akan tetapi, model full e-learning kurang baik dari kedua model yang lainnya. Ini menunjukkan bahwa e-learning tidak berarti dapat menggantikan model belajar konvensional di dalam kelas, tetapi dapat memperkuat model pembelajaran konvensional melalui pengayaan konten dan pengembangan teknologi pendidikan (Cisco lewat Kamarga, 2002:8).

Berdasarkan temuan, walaupun pembelajaran full e-learning, masih belum memberikan hasil yang memuaskan, tetapi baik full e-learning maupun blended learning relatif dapat mengembangkan daya matematik mahasiswa. Temuan ini terlihat dengan terdapatnya perbedaan daya matematik mahasiswa yang signifikan antara tiga kelompok yang diamati pada kedua level perguruan tinggi yang berbeda (level A dan B). Seperti yang telah disebutkan, secara parsial daya matematik mahasiswa yang pembelajarannya melalui blended learning lebih baik daripada mahasiswa yang melalui model pembelajaran yang lainnya (full e-learning, dan konvensional). Hal ini mengandung makna bahwa untuk pembelajaran matematika, khususnya dalam meningkatkan daya matematik, belum sepenuhnya dapat meninggalkan peran pamong dan mengalihkannya secara total kepada teknologi sekalipun. Demikian pula kebalikannya, keberadaan pamong dalam pembelajaran dewasa ini tidak bisa optimal tanpa dukungan teknologi. Pembelajaran blended learning, menempatkan fungsi e-learning sebagai suplemen (tambahan). Artinya, mahasiswa membutuhkan pilihan belajar, apakah akan memanfaatkan materi e-learning atau tidak (Siahaan, 2003).

Pada model full e-learning mahasiswa belajar sepenuhnya melalui internet, dalam hal ini fungsi e-learning sebagai komplemen (pengganti) (Siahaan, 2003). Dengan demikian, mahasiswa otomatis harus belajar secara mandiri. Pada model ini, kemandirian dan tanggung jawab mahasiswa benar-benar sangat dibutuhkan. Hal ini sesuai dengan pendapat Wedemeyer (Simonson, 1999:2) menganggap kemandirian siswa sebagai hal yang penting dalam pendidikan jarak jauh. Berdasarkan pengamatan, kecenderungan belajar mandiri secara utuh masih belum terbentuk sepenuhnya di kalangan mahasiswa yang menjadi subjek penelitian ini. Hal ini sesuai dengan temuan Soekartawi (2004:60) mengenai e-learning, yang menunjukkan mahasiswa saat ini masih kurang aktif, sehingga harus diberi peringatan 
via surat atau e-mail dengan tembusan ke atasan.

Melalui identifikasi hasil penelitian, jika ditinjau dari aspek penyebab yang mempengaruhi pencapaian daya matematik mahasiswa, maka diperoleh antara lain prakondisi belajar berupa pengetahuan awal yang dikuasai dan model pembelajaran. Hal ini mengidentifikasi teori konvensional tentang keberhasilan belajar pada umumnya, yakni adanya dukungan faktor internal dan eksternal dalam pencapaian hasil akhir belajar. Pengetahuan awal merupakan perwujudan dari faktor internal, sedangkan rekayasa proses pembelajaran oleh dosen (pendidik) merupakan wujud dari faktor eksternal.

Penguasaan teknologi belajar melalui intensitas kunjungan belajar ke web-site sangat penting. Pada salah satu perguruan tinggi yang diamati pada penelitian ini (perguruan tinggi level B), daya matematik mahasiswa full elearning dapat menyamai mahasiswa yang pembelajarannya melalui blended learning. Hal ini dimungkinkan karena frekuensi login mahasiswa yang melalui full e-learning lebih banyak dibanding dengan yang melalui blended learning. Hal ini sejalan dengan pendapat Soekartawi (2003:10) yang menyebutkan bahwa e-learning dapat mengkondisikan baik pendidik maupun mahasiswa, untuk melakukan diskusi melalui internet yang dapat diikuti dengan jumlah peserta yang banyak sehingga menambah ilmu pengetahuan dan wawasan mahasiswa yang lebih luas.

Berdasarkan hasil tes terhadap penguasaan pengetahuan awal yang mendukung model pembelajaran berbasis $e$ - learning, pada dua level perguruan tinggi tersebut dapat dikatakan cukup memadai. Dalam artian, secara umum mahasiswa memiliki dasar yang cukup untuk mengikuti program pembelajaran berbasis teknologi internet, maupun penguasaan pengetahuan awal untuk meningkatkan daya matematik.

Fenomena daya matematik bila dikaitkan dengan kecenderungan penguasaan tekonologi prasyarat, dapat memberi bukti bahwa teknologi berbasis internet masih perlu dikembangkan dalam budaya belajar kita, khususnya pada pembelajaran matematika. Hasil penelitian menunjukkan bahwa mahasiswa memanfaatkan materi e-learning sebagai sarana yang dapat menambah wawasan materi perkuliahan yang sedang dipelajarinya. Dalam artian elearning belum menjadi menu utama dalam budaya belajar mahasiswa.

Berdasarkan hasil dari keterkaitan semua faktor (model pembelajaran, level perguruan tinggi, pengetahuan awal, durasi login, dan daya matematik), dapat dikatakan bahwa pengelompokkan perguruan tinggi tidak berpengaruh terhadap peningkatan daya matematik mahasiswa. Hal tersebut berlaku bagi semua model pembelajaran. Daya matematik mahasiswa dapat dipengaruhi oleh penguasaan pengetahuan awalnya dan model pembelajaran. Piaget (Dahar, 1989) menegaskan bahwa pengetahuan yang dibangun dalam pikiran anak, bukan semata-mata diperoleh secara pasif oleh seseorang, melainkan hal tersebut telah disesuaikan dengan tingkat perkembangan intelektual dan pengalaman berpikirnya, dan diwujudkan melalui tindakan. Berda- 
sarkan pendapat Piaget tersebut, maka pembelajaran akan efektif dan menghasilkan daya matematik yang baik, jika pengetahuan awal yang dimiliki mahasiswa baik.

Secara parsial dapat dijelaskan sebagai berikut, pengaruh model pembelajaran pada perguruan tinggi level A, menunjukkan perbedaan yang signifikan pada pencapaian daya matematik mahasiswa di antara ketiga model pembelajaran (full e-learning, blended learning, dan konvensional). Model blended learning lebih baik dibanding model pembelajaran lainnya, dan model full elearning kurang baik dibanding model pembelajaran lainnya. Tidak terdapat perbedaan yang signifikan sikap mahasiswa terhadap e-learning matematika antara model full e-learning dan blended learning. Akan tetapi, pada perguruan tinggi level B, tidak terdapat perbedaan yang signifikan daya matematik mahasiswa di antara ketiga model pembelajaran tersebut.

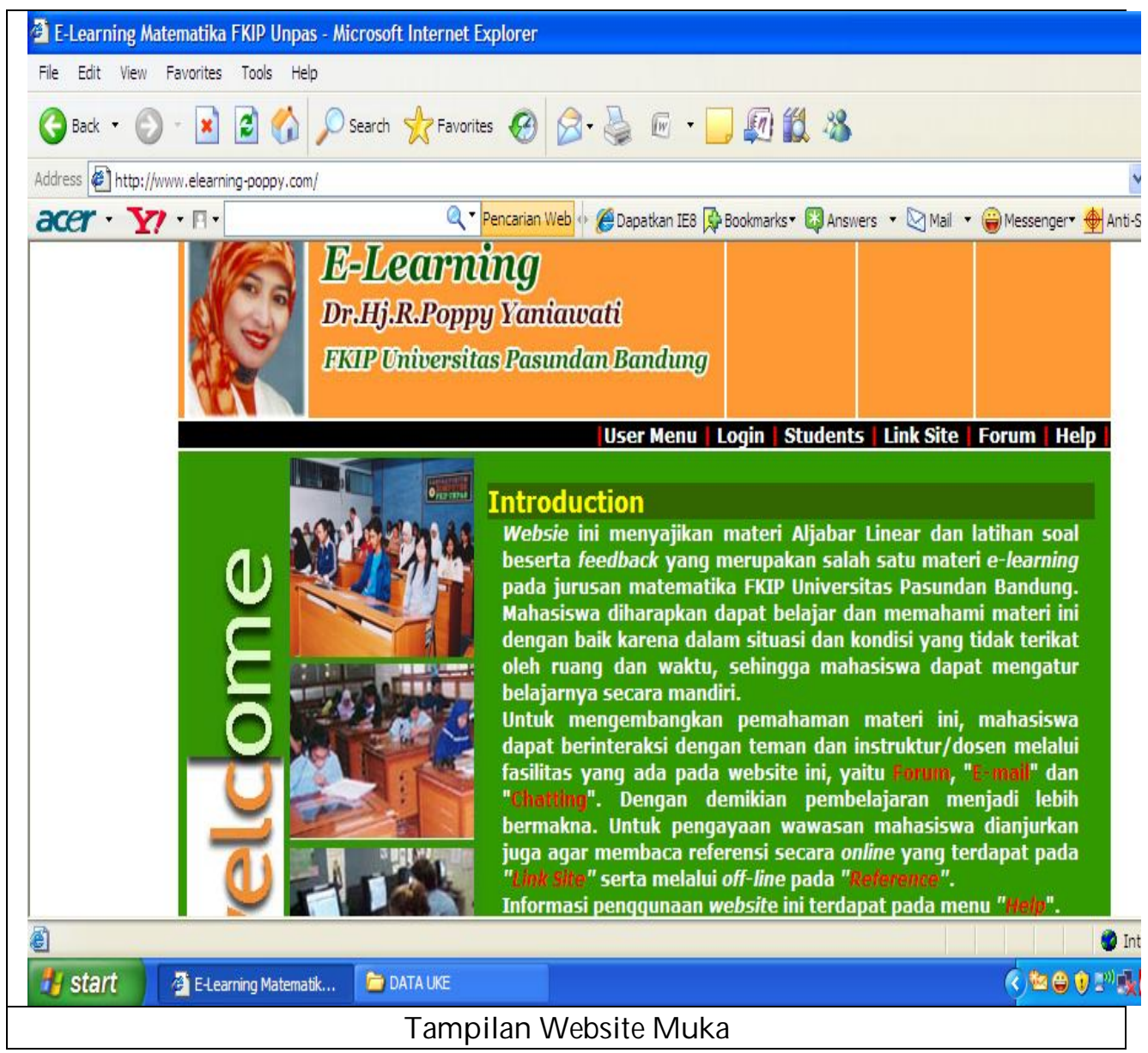

Gambar 1. Tampilan Web Site Muka E-Learning 
Bahkan, model full e-learning mempunyai sikap terhadap e-learning yang lebih baik dibanding blended learning. Dengan demikian, berdasarkan temuan di atas pada kedua level perguruan tinggi tersebut, e-learning (baik full $e$ learning ataupun blended learning) mempunyai peluang yang cukup baik untuk meningkatkan daya matematik mahasiswa. Chaeruman (2004:8) menyarankan, salah satu pendekatan yang membangun keterampilan berpikir tingkat tinggi atau daya matematik siswa adalah resource-based learning, memiliki karakteristik dimana siswa diberikan berbagai ragam dan jenis bahan belajar, baik off-line maupun on-line.

Pemanfaatan teknologi (e-learning) oleh mahasiswa masih belum optimal. Dengan kata lain, hal tersebut masih berada pada tahap coba-coba. Namun demikian, beberapa mahasiswa sudah mulai aktif menggunakan forum diskusi dan bertanya pada dosen lewat email, walaupun tidak semua mahasiswa melakukannya. Fasilitas-fasilitas yang ada pada website dan dengan adanya feedback membuat mahasiswa termotivasi untukmenggunakannya. pada quiz, mahasiswa termotivasi untuk mencoba lagi sampai mendapatkan jawaban yang benar. Fasilitas website yang dirasakan kurang optimal penggunaannya adalah chatting. Mahasiswa merasa sulit menemukan waktu yang cocok dengan dosennya dalam ber-chatting. Tampilan web site muka e-learning dapat dilihat pada Gambar 1.

\section{PENUTUP}

Berdasarkan hasil penelitian yang telah dikemukakan pada bagian terdahulu, maka diambil kesimpulan sebagai berikut.

- Terdapat perbedaan yang signifikan daya matematik antara mahasiswa calon guru yang belajarnya melalui full e-learning, blended-learning, dan pembelajaran konvensional. Daya matematik mahasiswa yang melalui blended learning lebih baik dibandingkan melalui pembelajaran full e-learning dan konvensional. Akan tetapi, mahasiswa yang melalui full e-learning kurang baik dibandingkan dengan pembelajaran konvensional.

- Pada perguruan tinggi level A, terdapat perbedaan yang signifikan daya matematik antara mahasiswa calon guru yang belajarnya melalui full e-learning, blended-learning, dan pembelajaran konvensional. Daya matematik mahasiswa yang melalui blended learning lebih baik dibandingkan melalui pembelajaran full e-learning dan konvensional. Akan tetapi, mahasiswa yang melalui full e-learning kurang baik dibandingkan dengan pembelajaran konvensional. Berbeda halnya pada perguruan tinggi level B (yang memiliki pengetahuan awal relatif kurang daripada level A), tidak terdapat perbedaan yang signifikan daya matematik antara mahasiswa pada ketiga model pembelajaran (full e-learning, blendedlearning, dan konvensional).

- Jika ditinjau dari aspek pengetahuan awal, baik mahasiswa unggul maupun asor, model blended learning lebih 
mengembangkan daya matematikmahasiswa dibandingkan dengan pembelajaran yang lainnya. Demikian pula pada perguruan tinggi level A, baikmahasiswa unggul maupun asor, model blended learning lebih mengembangkandaya matematik mahasiswa dibandingkan dengan pembelajaran yang lainnya. Khusus pada mahasiswa unggul, pembelajaran konvensional ternyata lebih memberikan kontribusi terhadap pengembangan daya matematik dibandingkan dengan full e-learning. Akan tetapi, daya matematik mahasiswa asor tidak menunjukkan perbedaan yang signifikan antara mahasiswa yang melalui pembelajaran konvensional dan full e-learning.

- Terdapat korelasi yang signifikan antara daya matematik dengan pengetahuan awal, akan tetapi tidak terdapat korelasi antara daya matematik dengan durasi login.

\section{UCAPAN TERIMA KASIH}

Ucapan terima kasih yang setinggitingginya penulis sampaikan kepada berbagai pihak yang telah memberikan banyak masukan terhadap penulisan artikel hasil penelitian ini, khususnya para editor. Terima kasih pula untuk Tim Redaksi Cakrawala Pendidikan yang telah mempublikasikan artikel ini. Semoga artikel ini dapat bermanfaat bagi pembaca, dan menjadikan inspirasi untuk penelitian selanjutnya.

\section{DAFTAR PUSTAKA}

Chaeruman, U. A. 2004. Integrasi Teknologi Telekomunikasi dan Informasi
(TTI) ke dalam Pembelajaran. Makalah Seminar Nasional Teknologi Pembelajaran. Jakarta: Universitas Terbuka.

Cute, A., Thompson, M., and Hancock, B. 1999. Handbook of Distance Learning. The McGraw-Hill.

Dahar, R. W. 1989. Teori-teori Belajar. Jakarta: Erlangga.

Kamarga, H. 2002. Belajar Sejarah melalui E-learning. Jakarta: Intimedia.

Linde, E. 2004. Online Teaching and Learning. Makalah Seminar pada tanggal 16 Pebruari 2004 di Unpad Bandung.

National Council of Teacher of Mathematics (NCTM). 2000. Principles and standards for School Mathematics. Reston, VA: NCTM.

Siahaan, S. 2003. "E-Learning (Pembelajaran Elektronik) sebagai Salah Satu Alternatif Kegiatan Pembelajaran". Jurnal Pendidikan dan Kebudayaan. No. 042. Tahun Ke-9. Mei 2003.

Simonson, M., et al. 1999. Theory and Distance Education: A New Discussion. [Online]. Tersedia: http:// www.uni-oldenburg.de/zef/cdefound/simons99.htm [23 Juni 2004].

Soekartawi. 2003. E-learning di Indonesia dan Prospeknya di Masa Mendatang. Makalah disampaikan pada Seminar Nasional E-learning Perlu 
E-Library' di Universitas Kristen Petra Surabaya. [Online]. Tersedia: Http://ncuvl.petra.ac.id/indonesi a bimbing/elearning2.pdf.

Soekartawi. 2004. "Beberapa Kesulitan dalam Pelaksanaan Pembelajaran Berbasis Web pada Sistem Pendidikan Jarak Jauh". Teknologi
Pembelajaran. Jakarta: PUSTEKKOM.

Thompson, et al. 2000. Perspective in Quality online Education. [Online]. Tersedia: http://www.sloan-c.org/ publications/view/v2n7/pdf. 